Article

\title{
Do Movement Patterns of GPS-Tracked Cattle on Extensive Rangelands Suggest Independence among Individuals?
}

\author{
Mitchell B. Stephenson ${ }^{1, *}$ and Derek W. Bailey ${ }^{2}$ \\ 1 Panhandle Research and Extension Center, University of Nebraska-Lincoln, Scottsbluff, NE 69361, USA \\ 2 Department of Animal and Range Sciences, New Mexico State University, Las Cruces, NM 88001, USA; \\ dwbailey@ad.nmsu.edu \\ * Correspondence: mstephenson@unl.edu; Tel.: +1-308-632-1355
}

Academic Editor: Courtney L. Daigle

Received: 31 May 2017; Accepted: 4 July 2017; Published: 15 July 2017

\begin{abstract}
In behavioral studies, cattle within the same pasture are not considered as independent experimental units because of the potential confounding effects of the herd's social interactions. However, evaluating cattle behavior on extensive rangelands is logistically challenging for researchers, and treating individual animals as independent experimental units may be beneficial for answering specific research questions. The objective of this study was to evaluate the association patterns among global positioning system (GPS)-tracked cattle at six different study sites in the western United States. A Half-Weight Index (HWI) association value was calculated for each pair of GPS-tracked cows (i.e., dyad) to determine the proportion of time that cattle were within $75 \mathrm{~m}$ and $500 \mathrm{~m}$ of each other. Cattle at two study sites exhibited relatively low mean HWI-association values (i.e., less than $0.23 \mathrm{HWI}$ ); whereas, cattle at other study sites tended to have greater mean HWI associations (i.e., greater than $0.35 \mathrm{HWI}$ ). Distinguishing features between study sites with low and high association values were the management of cattle prior to the study, herd size, pasture size, and the number of watering points. However, at all ranches except one, at least $75 \%$ of all dyadic associations had HWI values of less than 0.5 at $500 \mathrm{~m}$, indicating that most of the GPS-tracked cows were greater than $500 \mathrm{~m}$ from each other for over $50 \%$ of tracking period. While interactions among cattle in the same pasture are often inevitable, our data suggests that under some situations, movement patterns of a sub-set of individual GPS-tracked cows may have levels of independence that are sufficient for analysis as individual experimental units. Understanding the level of independence among GPS-tracked cattle may provide options for analysis of grazing behavior for individual cattle within the same pasture.
\end{abstract}

Keywords: cattle; social associations; GPS; behavior

\section{Introduction}

The use of Global Positioning System (GPS) collars has allowed us to make great strides in our understanding of livestock behavior and distribution patterns of animals across diverse landscapes [1-5]. However, the ability to collect large amounts of tracking data with the use of GPS collars has often complicated experimental designs and statistical analyses. Two major statistical problems that arise from GPS tracking data are auto-correlation of consecutive positions from an individual animal and failure to achieve independence among multiple GPS-tracked animals within the same pasture or herd $[5,6]$.

Several studies have evaluated the effect of auto-correlated data with the use of GPS- and radio telemetry-tracked livestock and wildlife [7-9]. Perotto-Baldivieso et al. [9] determined that a $120 \mathrm{~min}$ GPS fix sample interval was sufficient to limit auto-correlation of consecutive GPS locations for home 
range analysis of GPS-tracked cattle grazing in southwest USA. Fewer studies have evaluated factors that may influence the level of independence exhibited among individual GPS-tracked cattle within the same pasture.

Cattle are social animals and typically associate within groups when grazing on rangelands [10-13]. This social behavior often creates a synchronization of behaviors (i.e., resting, grazing, and moving to water) within a herd [14,15]. Because of these social behaviors and interactions, individual GPS-tracked cows grazing within the same pasture are typically not considered as statistically independent experimental units within grazing behavior studies. Independence of experimental units is an important component of statistically valid research [16]. Because of the potential correlation between animals, values of all individually tracked animals within the same pasture or herd are usually averaged to avoid pseudo-replication. Pooling all data from GPS-tracked livestock within the same pasture makes research that evaluates variability in home ranges, terrain use, resource selection, and behavioral functions of individual animals difficult to conduct. Establishing several pastures and herds on extensive rangelands to achieve complete independence of experimental units often makes GPS-tracking research logistically impractical and cost prohibitive [5,17]. However, some studies have indicated that there may be a level of independence among cattle within the same pasture that is sufficient to address specific research questions using the individual as the experimental unit $[12,18]$.

Understanding the level of independence of GPS-tracked cattle grazing within the same pasture could potentially facilitate studies evaluating factors that affect terrain use of livestock or specific grazing behaviors among individual animals or individual groups within the same pasture. The objective of this study was to conduct an overview of GPS-tracked cattle grazing at six study sites to identify potential differences in independence among cattle grazing within herds of varying sizes under different management situations on diverse and extensive rangelands in the western United States. The methods used in this study do not provide rigorous statistical tests of independence between GPS-tracked cattle, but help facilitate observational understanding of the social associations and independence among a sub-set of GPS-tracked cows within larger herds [6]. Knowledge of potential factors affecting social association and independence among GPS-tracked cattle provides needful information for future analyses of cattle grazing behaviors within different management scenarios.

\section{Material and Methods}

\subsection{Study Sites}

GPS tracking data were collected from cattle on six ranches as part of a study evaluating genotypic differences of cattle that grazed at varying distances from water, slopes, and elevations [19]. These ranches are located in areas with varying levels of topography and vegetation types. The Carter Ranch, the Chihuahuan Desert Rangeland Research Center (CDRRC) and the Corona Range and Livestock Research Center (CRLRC) are located in areas with relatively gentle terrain; whereas, the Evans Ranch and the Montana State University Thackeray Ranch are located in rugged terrain. The Todd Ranch is the largest of the study sites and the most diverse, with both mountainous and rugged terrain, and large areas of gentle plains (Table 1). 
Table 1. Ranch location and description of the abiotic factors that affect cattle distribution at the New Mexico State University (NMSU) Corona Range and Livestock Research Center (CRLRC), NMSU Chihuahuan Desert Range Research Center (CDRRC), Montana State University (MSU) Thackeray Ranch, Carter Ranch, Todd Ranch, and Evans Ranch.

\begin{tabular}{|c|c|c|c|c|c|c|c|}
\hline Ranch & Latitude & Longitude & Terrain & $\begin{array}{l}\text { Elevation } \\
\text { (m) }\end{array}$ & Slope (\%) & $\begin{array}{l}\text { Maximum } \\
\text { Distance to } \\
\text { Water }(\mathbf{k m})\end{array}$ & $\begin{array}{c}\text { Annual } \\
\text { Precipitation } \\
(\mathrm{mm})^{*}\end{array}$ \\
\hline $\begin{array}{l}\text { NMSU } \\
\text { CRLRC }\end{array}$ & $34^{\circ} 15^{\prime} \mathrm{N}$ & $105^{\circ} 27^{\prime} \mathrm{W}$ & Rolling & 1765-1851 & $0-32$ & 4.7 & $\begin{array}{c}317 \text { in } 2010 \\
159 \text { in } 2011 \\
134 \text { in } 2012 \\
(370)\end{array}$ \\
\hline $\begin{array}{l}\text { NMSU } \\
\text { CDRRC }\end{array}$ & $32^{\circ} 31^{\prime} \mathrm{N}$ & $106^{\circ} 48^{\prime} \mathrm{W}$ & $\begin{array}{l}\text { Rolling with } \\
\text { arroyos }\end{array}$ & $1250-1402$ & $1-15$ & 10.0 & $168(234)$ \\
\hline $\begin{array}{l}\text { MSU } \\
\text { Thackeray } \\
\text { Ranch }\end{array}$ & $48^{\circ} 21^{\prime} \mathrm{N}$ & $109^{\circ} 36^{\prime} \mathrm{W}$ & Rugged & $1170-1400$ & 0-107 & 1.5 & $328(290)$ \\
\hline $\begin{array}{l}\text { Carter } \\
\text { Ranch }\end{array}$ & $32^{\circ} 29^{\prime} \mathrm{N}$ & $109^{\circ} 16^{\prime} \mathrm{W}$ & Rolling & $1081-1250$ & $0-29$ & 3.1 & 137 (249) \\
\hline $\begin{array}{l}\text { Todd } \\
\text { Ranch }\end{array}$ & $32^{\circ} 15^{\prime} \mathrm{N}$ & $109^{\circ} 56^{\prime} \mathrm{W}$ & $\begin{array}{l}\text { Rugged and } \\
\text { gentle }\end{array}$ & 1276-2010 & $1-130$ & 4.8 & 237 (309) \\
\hline $\begin{array}{l}\text { Evans } \\
\text { Ranch }\end{array}$ & $32^{\circ} 30^{\prime} \mathrm{N}$ & $108^{\circ} 31^{\prime} \mathrm{W}$ & $\begin{array}{l}\text { Rugged and } \\
\text { moderate }\end{array}$ & 1670-1902 & $1-77$ & 4.8 & $188(402)$ \\
\hline
\end{tabular}

* Annual precipitation during the year of tracking with the long-term average precipitation in parentheses.

The Carter Ranch is located $25 \mathrm{~km}$ north of San Simon, AZ, USA. Terrain is gentle with some slopes. Dominant grasses are tobosa (Pleuraphis mutica Buckley), dropseeds (Sporobolus spp.), and grama grasses (Bouteloua spp). Dominant shrubs include honey mesquite (Prosopis glandulosa Torr.), creosote (Larrea tridentata (DC.) Coville), catclaw acacia (Acacia greggii A. Grayand), and whitethorn acacia (Acacia constricta Benth).

The CDRRC is managed by New Mexico State University and is located approximately $37 \mathrm{~km}$ north of Las Cruces, NM, USA. Terrain at the CDRRC is rolling and interspersed with arroyos and small ridges. Common grasses include dropseeds, threeawns (Aristida spp.), and bush muhly (Muhlenbergia porteri Scribn. ex Beal). Dominant shrubs are honey mesquite and creosote.

The CRLRC also is managed by New Mexico State University and is located $13 \mathrm{~km}$ east of Corona, NM, USA. Terrain is rolling with undulating plains. Dominant grasses are blue grama (Bouteloua gracilis (Willd. ex Kunth) Lag. ex Griffiths), New Mexico feathergrass (Hesperostipa neomexicana (Thurb. ex J.M. Coult.) Barkworth), and other grama grasses. Tree cholla (Cylindropuntia imbricata (Haw.) F.M. Knuth) are abundant, and juniper trees (Juniperus ssp.) are scattered throughout the overstory within the study pasture.

The Evans Ranch is located $57 \mathrm{~km}$ southwest of Silver City, NM, USA. Terrain is rugged in some areas, but there are flat bottom areas and gentle to moderate slopes. Sideoats grama (Bouteloua curtipendula (Michx.) Torr.) is the dominant grass, but other grama grasses and tobosa are common. Juniper, live oak (Quercus spp.), and mountain mahogany (Cercocarpus spp.) are the dominant woody species.

The Thackeray Ranch is managed by Montana State University and is located in the Bear's Paw Mountains approximately $25 \mathrm{~km}$ south of Havre, MT, USA. Terrain is mountainous with steep slopes, dividing ridges, and narrow bottom areas. Dominant grasses at the site are Kentucky bluegrass (Poa pratensis L.), rough fescue (Festuca campestris Rydb.), bluebunch wheatgrass (Pseudoroegneria spicata (Pursh) Á. Löve), and Idaho fescue (Festuca idahoensis Elmer). Less than $15 \%$ of the pasture contains trees such as ponderosa pine (Pinus ponderosa Lawson \& C. Lawson) and aspen (Populus tremuloides Michx.).

The Todd Ranch is located $11 \mathrm{~km}$ northwest of Willcox, AZ, USA. Terrain is variable with over $50 \%$ of the pasture containing rough, mountainous terrain and the remaining area containing bottom 
lands with gentle slopes. Dominant grasses are dropseeds and sacaton (Sporobolus airoides Torr.), grama grasses, threeawns, and tobosa. Common trees and shrubs include mesquite (Prosopis spp.), desert willow (Chilopsis linearis (Cav.) Sweet), acacia (Acacia spp.), juniper, and oak.

\subsection{GPS Cattle Tracking}

Cattle fitted with GPS collars were randomly selected from the cows that grazed within the study pastures, with the exception of cows at the CRLRC, the Todd Ranch, and the Thackeray Ranch in 2011. At the CRLRC and Todd Ranch in 2011, visual observations (three to seven days of observation) of cattle grazing locations were collected before fitting cattle with GPS collars. These observations were used to select cows grazing at different elevations, slopes, and distances from water. Equal numbers of cows observed grazing at the high and low extremes of these criteria were selected for GPS tracking. Cows tracked at the Thackeray Ranch were developed as part of another study [20] and were all sired by the same bull (i.e., half-siblings). These cows were typically managed separately from other cattle within the study pasture before being turned out onto study pastures in the late summer of 2011. Herd sizes varied from 37 cow at the Evans Ranch to 250 cows at the Todd Ranch (Table 2).

Table 2. Periods of cattle tracking, length of studies, description of study pastures, herd size, and number of global positioning system (GPS)-tracked cows at the New Mexico State University (NMSU) Corona Range and Livestock Research Center (CRLRC), NMSU Chihuahuan Desert Range Research Center (CDRRC), Montana State University (MSU) Thackeray Ranch, Carter Ranch, Todd Ranch, and Evans Ranch.

\begin{tabular}{|c|c|c|c|c|c|c|c|c|}
\hline Ranch & Start Date & End Date & $\begin{array}{c}\text { Length of } \\
\text { Tracking } \\
\text { (day) }\end{array}$ & $\begin{array}{l}\text { Pasture } \\
\text { Size (ha) }\end{array}$ & $\begin{array}{c}\text { Water } \\
\text { Sources }\end{array}$ & $\begin{array}{c}\text { Herd } \\
\text { Size }\end{array}$ & $\begin{array}{l}\text { Number of } \\
\text { GPS-Tracked } \\
\text { Cows }(n)\end{array}$ & $\begin{array}{c}\text { Number of } \\
\text { Dyadic } \\
\text { Associations } 1\end{array}$ \\
\hline \multirow{3}{*}{$\begin{array}{l}\text { NMSU } \\
\text { CRLRC }\end{array}$} & $5 / 17 / 2010$ & $7 / 19 / 2010$ & 63 & 1601 & 1 & 120 & 14 & 91 \\
\hline & $5 / 19 / 2011$ & $6 / 22 / 2011$ & 34 & 1601 & 1 & 110 & 12 & 66 \\
\hline & $6 / 28 / 2012$ & 8/17/2012 & 50 & 1601 & 1 & 140 & 17 & 136 \\
\hline $\begin{array}{l}\text { NMSU } \\
\text { CDRRC }\end{array}$ & $6 / 29 / 2011$ & $8 / 1 / 2011$ & 33 & 3990 & 1 & 43 & 16 & 120 \\
\hline $\begin{array}{c}\text { MSU } \\
\text { Thackeray } \\
\text { Ranch }\end{array}$ & $8 / 8 / 2011$ & 9/14/2011 & 37 & 336 & 3 & 213 & 17 & 136 \\
\hline $\begin{array}{l}\text { Carter } \\
\text { Ranch }\end{array}$ & $10 / 21 / 2011$ & $1 / 6 / 2012$ & 77 & 4776 & 6 & 125 & 11 & 55 \\
\hline $\begin{array}{c}\text { Todd } \\
\text { Ranch }\end{array}$ & 1/15/2011 & $4 / 15 / 2011$ & 90 & 9740 & 20 & 250 & 15 & 105 \\
\hline $\begin{array}{l}\text { Evans } \\
\text { Ranch }\end{array}$ & $8 / 26 / 2012$ & $10 / 21 / 2012$ & 56 & 1994 & 2 & 37 & 15 & 105 \\
\hline
\end{tabular}

${ }^{1}$ Number of dyadic associations $n \times(n-1) / 2$.

All cows were tracked with Lotek 3300 GPS collars (Lotek Wireless, Newmarket, ON, Canada). Number of tracked cows ranged from 11 to 17 cows (Table 2). Cows at the Carter and Todd Ranches were tracked at 15 min intervals for two to three months (Table 2), while cows at the CDRRC, CRLC, Evans Ranch, and Thackeray Ranch were tracked at $10 \mathrm{~min}$ intervals for one to two months. Cows had calves during the tracking period at the CDRRC, CRLRC, Evans Ranch, and Thackeray Ranch. Cows at the Carter and Todd Ranches were tracked in the autumn and winter after calves had been weaned.

\subsection{Analysis of Association Patterns}

Data from the GPS-tracked cows were analyzed using the social association software program ASSOC1 4.0 (Weber et al. 2001). The ASSOC1 program evaluates associations among individuals based on the animals' Universal Transverse Mercator locations and time signatures on radio-telemetry or GPS-tracked wildlife and livestock. ASSOC1 creates pairwise association matrices of the number of recorded GPS locations of animals within a user defined distance at the same time. ASSOC1 
has been used to assess spatio-temporal independence of GPS- or radio-telemetry tracked elk (Cerous elaphus [6,21-23]), mule deer (Odocoileus hemionus [22,24]), and cattle (Bos spp. [12,18]).

To evaluate spatio-temporal association and independence levels between individual pairs of GPS-tracked cattle (i.e., dyads), two spatial distances were used based on independence values used in previous research for cattle and wildlife tracking studies. In one study, dyadic association levels of cows were considered independent if more than $75 \%$ of the GPS locations between cows were greater than $75 \mathrm{~m}$ apart (equivalent to a 1.8 ha area)[18]. At a larger spatial scale, mule deer were considered independent if greater than $50 \%$ of the GPS locations were greater than $500 \mathrm{~m}$ apart (equivalent to $78.5 \mathrm{ha}$ )[24]. While these criteria were arbitrary in assigning independence to the movements to cattle or wildlife, we assumed that if cattle met these spatio-temporal criteria, movements and selection of grazing sites would be predominantly independent among dyads. Within our study, when dyads were within $75 \mathrm{~m}$ of each other, cattle were likely within the same group or in relatively close spatial contact. The $500 \mathrm{~m}$ spatial criteria likely represented dyads of GPS-tracked cows that were within the same general feeding site [25], but may or may not have had visual contact with one another because of topography or vegetation structure.

If cattle were within $200 \mathrm{~m}$ of water, they were likely resting or drinking and not grazing. We were more interested in evaluating associations that occurred away from water; therefore, associations among dyads were evaluated with only GPS locations at distances farther than $200 \mathrm{~m}$ from water to exclude social interactions that occurred at water. The Thackery ranch was the only location that had riparian areas, but they were small $(<0.1 \mathrm{ha})$.

Strength of association for each dyad was calculated from the ASSOC1 association matrices using a Half-Weight Index (HWI) association measure. The HWI is one the most commonly used measures of association in studies evaluating association patterns between individual animals [26], and has been used in understanding factors that affect associations of cattle [27] and bison [28]. The HWI calculated the proportion of the GPS location fixes where cattle were within 75 and $500 \mathrm{~m}$ distances from each other relative to the total number of GPS location fixes recorded for each animal [29]. The equation for the HWI is:

$$
H W I=\frac{X}{X+0.5\left(Y_{a}+Y_{b}\right)}
$$

where $X$ is the number of GPS fixes where cows $A$ and B were located within a defined distance from each other, and $Y_{a}$ and $Y_{b}$ are the total number of GPS fixes where cows A and B were observed individually. A HWI value of 1.0 represents a dyad where GPS-tracked cows were within a defined distance for $100 \%$ of the GPS fixes and a HWI value of 0.0 represents a dyad where GPS-tracked cows were never within the defined distance. The HWI is the least biased measure of association in cases where individual animals have different numbers of observations or total GPS-recorded locations [29]. Differences in the total number of GPS locations among cattle were the result of GPS-collars not recording locations for all 10- or 15-min intervals because of poor satellite reception or mechanical failure of the collar. However, most GPS-tracked cows recorded locations at greater than $85 \%$ of the total potential points, and any cow tracked that recorded less than $66 \%$ of the total locations was removed from the study. The total number of GPS-tracked cows at the study sites ranged from 11 to 17 cows grazing in herds of 37 to 250 cows (Table 2).

The mean daily distance between the least and most associated dyads at $500 \mathrm{~m}$ were determined to assess the temporal variability of their associations. Data from each dyad were analyzed using the Pythagorean Theorem to determine the distance between tracked cattle at each recorded location fix. These distances were averaged over each day that cattle were within the study pastures.

\section{Results}

The strength of associations among GPS-tracked cattle at the different study sites was highly variable (Figures 1 and 2). While some dyads showed strong associations (e.g., one dyad at the CDRRC had a HWI greater than 0.8 at $500 \mathrm{~m}$ ), other dyads exhibited relative independence from each other 
at different spatial scales (e.g., HWI less than 0.1 at $500 \mathrm{~m}$ ). At $75 \mathrm{~m}$, associations among most of the dyads at the different study sites were relatively low (i.e., HWI less than 0.3).

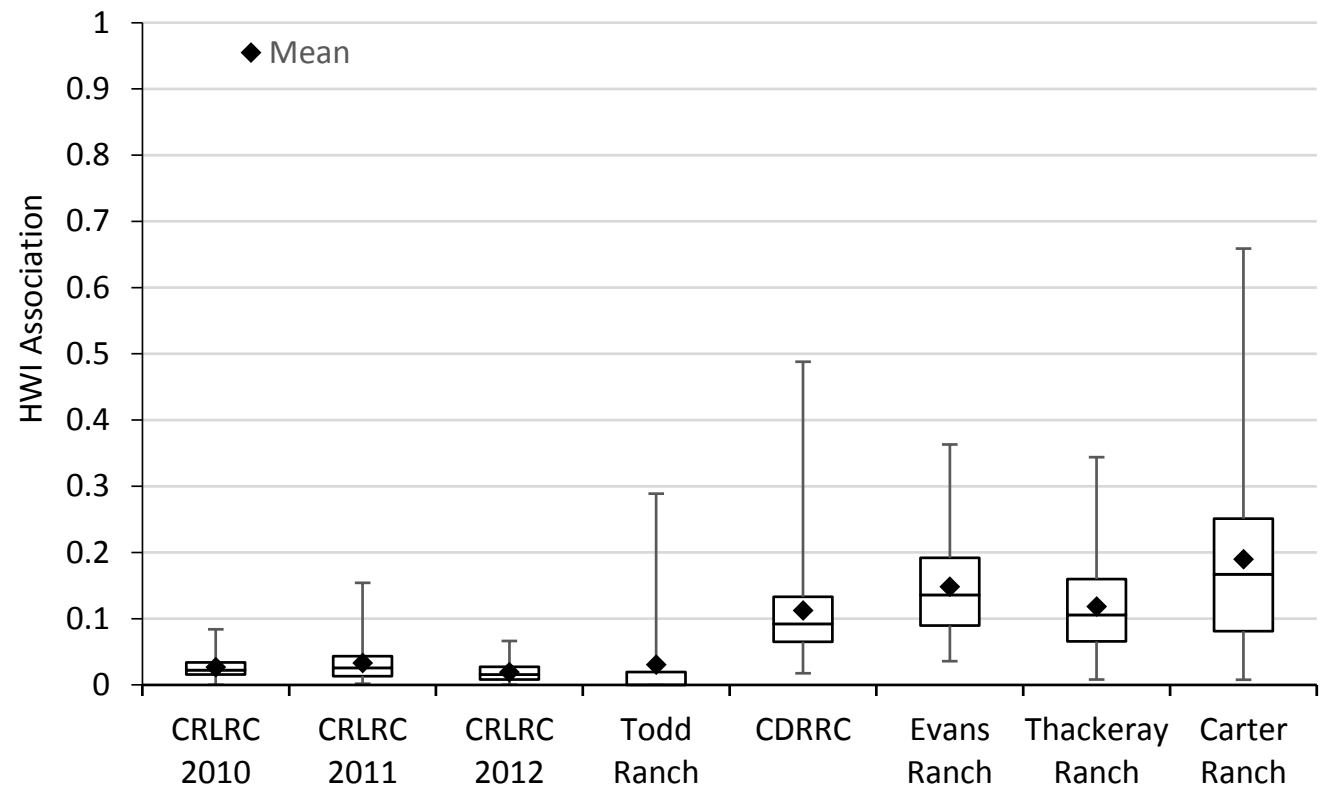

Figure 1. Box plots representing the minimum, 1st quartile, median, mean ( $)$, 3rd quartile, and maximum Half-Weight Index (HWI) association value of dyads of Global Positioning System (GPS)-tracked cattle at $75 \mathrm{~m}$ at the Corona Range and Livestock Research Center (CRLRC), Todd Ranch, Chihuahuan Desert Range Research Center (CDRRC), Evans Ranch, Thackeray Ranch, and Carter Ranch.

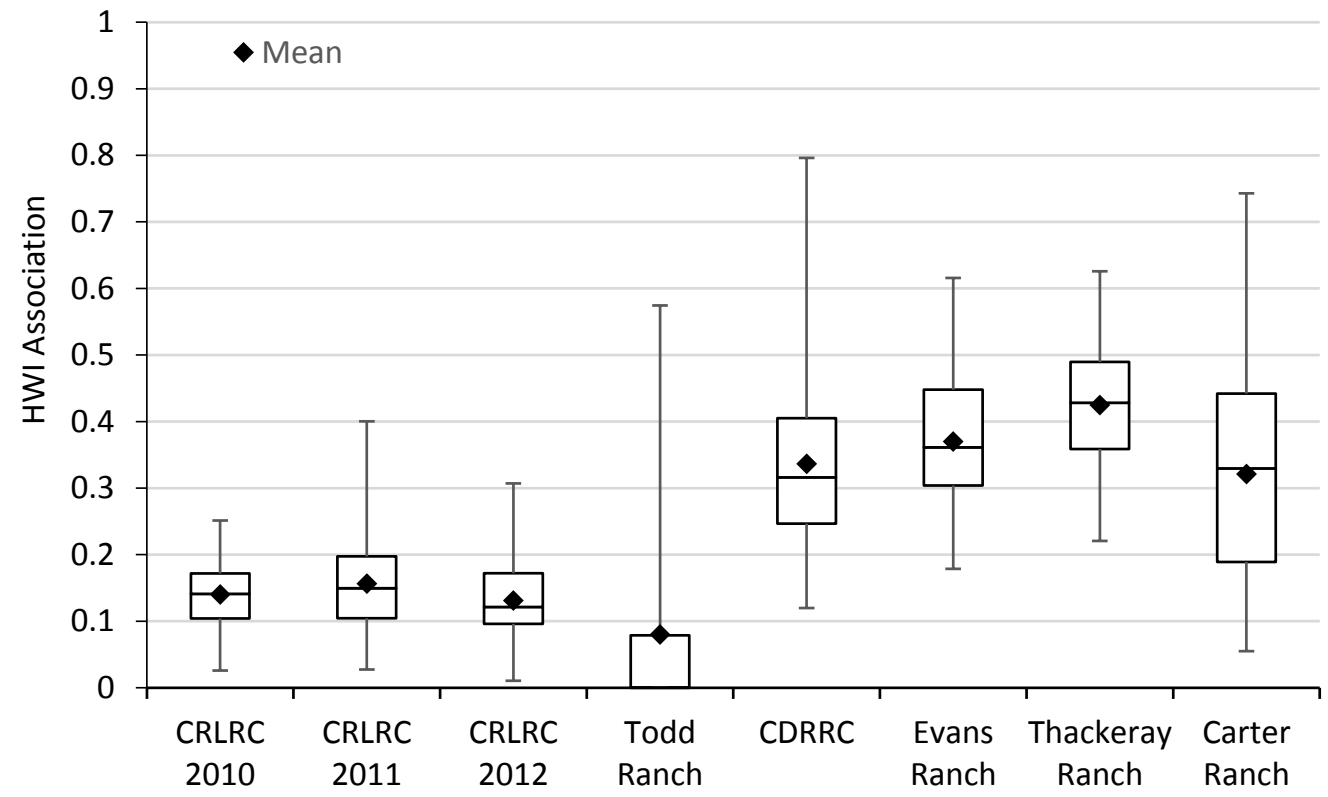

Figure 2. Box plots representing the minimum, 1st quartile, median, mean ( $)$, 3rd quartile, and maximum Half-Weight Index (HWI) association value of dyads of Global Positioning System (GPS)-tracked cattle at $500 \mathrm{~m}$ at the Corona Range and Livestock Research Center (CRLRC), Todd Ranch, Chihuahuan Desert Range Research Center (CDRRC), Evans Ranch, Thackeray Ranch, and Carter Ranch. 
All dyads at the CRLRC were at distances greater than $75 \mathrm{~m}$ for $91 \%, 84 \%$, and $93 \%$ of the GPS locations in 2010, 2011, and 2012, respectively (Figure 1). All dyads at the CRLRC were greater than $500 \mathrm{~m}$ from each other for at least $57 \%$ (i.e., HWI < 0.43) of the time that cattle were on the study pastures within different years (Figure 2). The mean daily distance between cows for the most associated dyad (HWI $=0.43$ at $500 \mathrm{~m}$ ) at the CRLRC in 2011 was greater than $500 \mathrm{~m}$ for 26 days during the study period, and less than $500 \mathrm{~m}$ for only 11 days (Figure 3A). For the least associated dyad (HWI $=0.12$ at $1000 \mathrm{~m}$ ), mean daily distance between cows was greater than $500 \mathrm{~m}$ in all days of the study period, and mean separation distances were usually greater than $1500 \mathrm{~m}$, suggesting that cows within this dyad nearly always grazed in different areas of the pasture (Figure 3A).

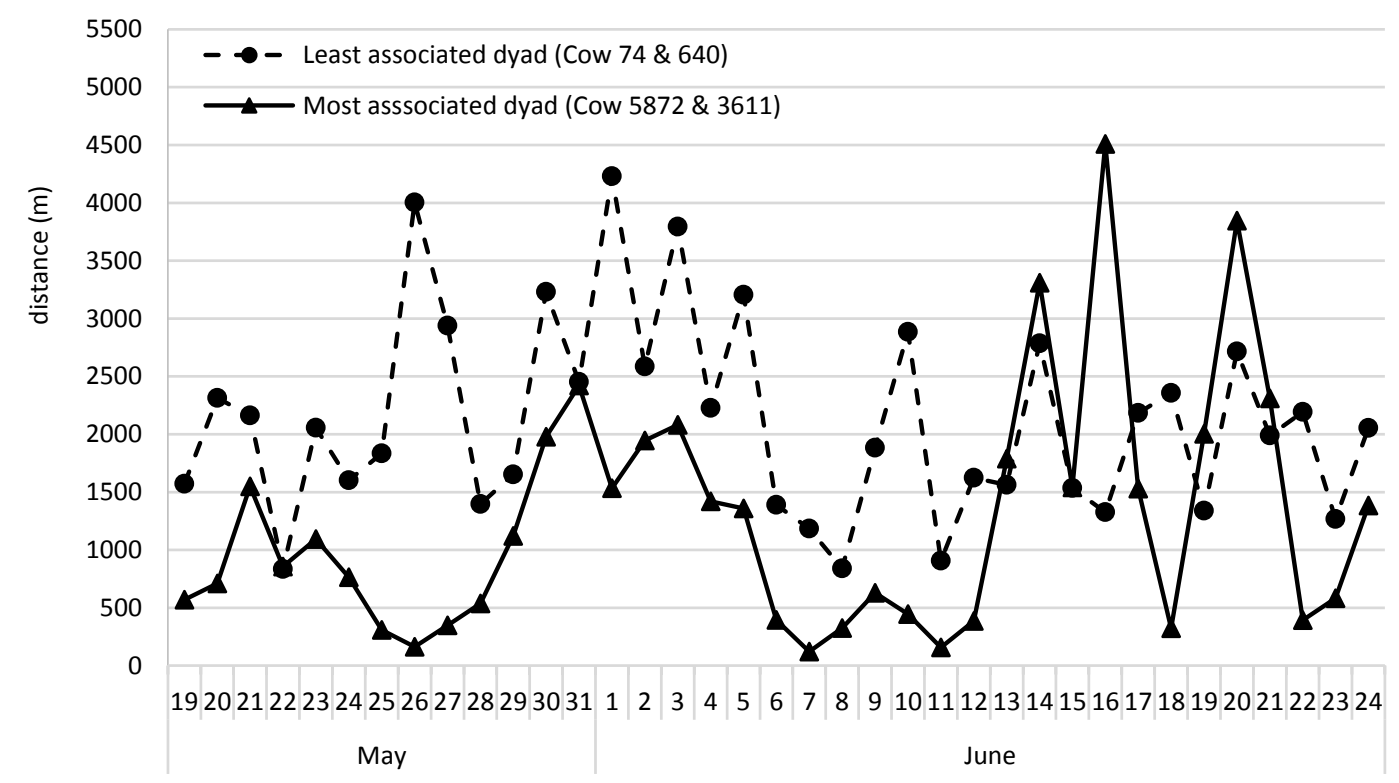

(A)

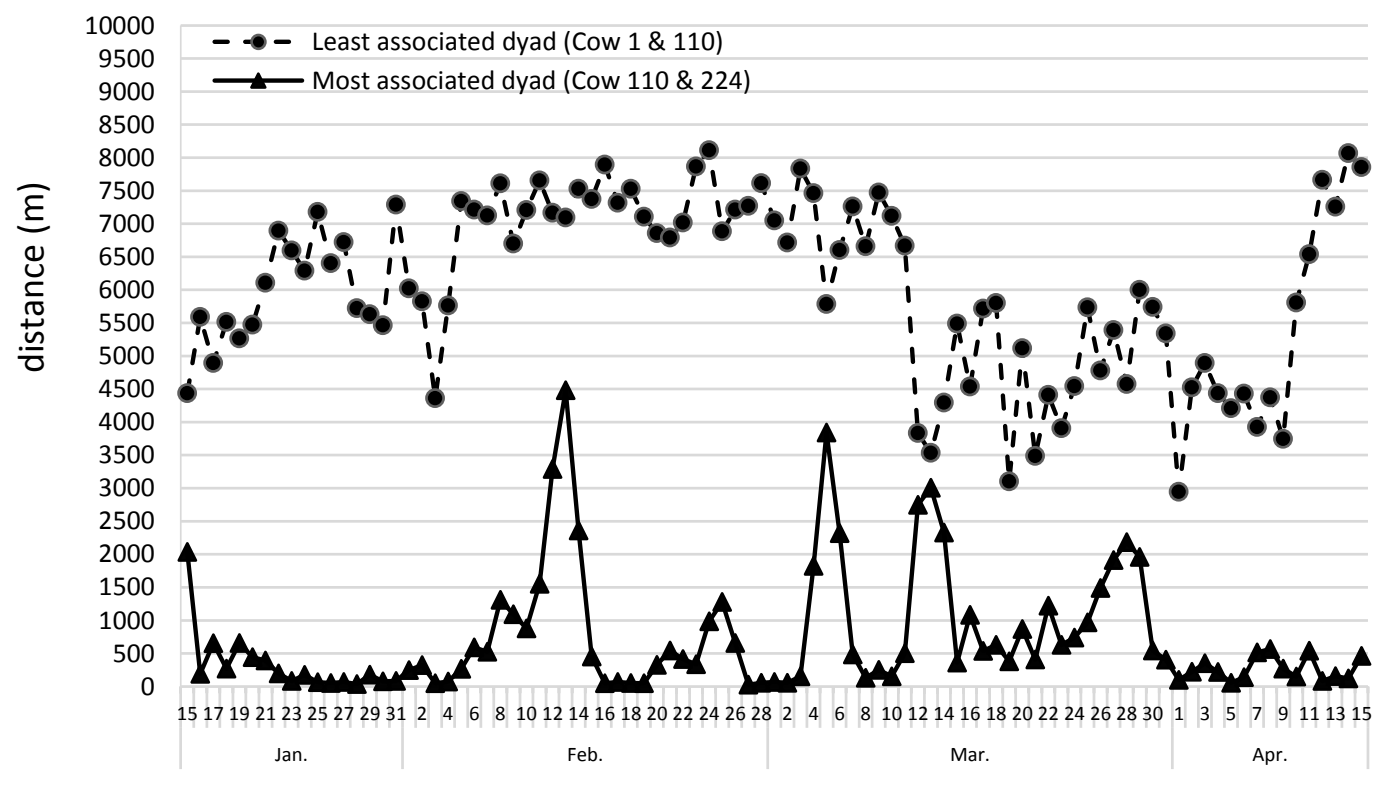

(B)

Figure 3. Mean daily distance between the least and most associated dyad of the GPS-tracked cows at $500 \mathrm{~m}$ at the (A) Corona Range and Livestock Research Center in 2011 and (B) Todd Ranch study sites. 
Cattle at the Todd Ranch were the only cows to exhibit complete independence (i.e., HWI $=0$ ) at the $75 \mathrm{~m}$ (54 dyads) and $500 \mathrm{~m}$ (45 dyads) spatial scales between some dyads (Figure 1). Nearly all dyads at the Todd Ranch had HWI association values less than 0.25 at $75 \mathrm{~m}$ (Figure 1). However, 2 cows had HWI values greater than 0.25 , indicating that this dyad did not meet the criteria for independence (Table 3). At $500 \mathrm{~m}$, three cows had HWI values greater than 0.52 with one or two other cows (Table 4), but most dyads had HWI values less than 0.1 at $500 \mathrm{~m}$ (Figure 2) suggesting that a high level of independence among most dyads existed during the tracking period. The daily distance between the least associated dyad (i.e., cow 1 and $110, \mathrm{HWI}=0.0$ at $500 \mathrm{~m}$ ) was usually greater than $5000 \mathrm{~m}$ (Figure 3B). Cow 1 and 110 grazed within different areas of the study pasture on opposite sides of a dividing ridge and rough topography. In contrast, the daily mean distance between the most associated dyad (i.e., Cow 110 and 224, HWI $=0.58$ at $500 \mathrm{~m}$ ) was less than $500 \mathrm{~m}$ for $55 \mathrm{~d}$ of the $90 \mathrm{~d}$ study (Figure 3B).

Table 3. Number of cows each cow was associated with at Half-Weight Index (HWI) association values greater than 0.25 at $75 \mathrm{~m}$ at the Corona Range Livestock Research Center (CRLRC), the Todd Ranch, the Chihuahuan Desert Range Research Center (CDRRC), the Evans Ranch, the Thackeray Ranch and the Carter Ranch.

\begin{tabular}{|c|c|c|c|c|c|c|c|c|c|}
\hline \multirow[t]{2}{*}{ Study Site } & \multicolumn{8}{|c|}{ Number of Associations at HWI $>0.25$ at $75 \mathrm{~m}$} & \multirow[b]{2}{*}{ Total } \\
\hline & 0 & 1 & 2 & 3 & 4 & & 6 & 7 & \\
\hline CRLRC 2010 & 14 & 0 & 0 & 0 & 0 & & 0 & 0 & 14 \\
\hline CRLRC 2011 & 12 & 0 & 0 & 0 & 0 & & 0 & 0 & 12 \\
\hline CRLRC 2012 & 17 & 0 & 0 & 0 & 0 & & 0 & 0 & 17 \\
\hline Todd Ranch & 13 & 2 & 0 & 0 & 0 & & 0 & 0 & 15 \\
\hline CDRRC & 5 & 6 & 3 & 2 & 0 & & 0 & 0 & 16 \\
\hline Evans Ranch & 5 & 5 & 3 & 0 & 1 & & 0 & 0 & 15 \\
\hline Thackeray Ranch & 10 & 3 & 3 & 1 & 0 & & 0 & 0 & 17 \\
\hline Carter Ranch & 1 & 3 & 2 & 1 & 3 & & 1 & 0 & 11 \\
\hline
\end{tabular}

Table 4. Number of cows each cow was associated with at Half-Weight Index (HWI) association values greater than 0.5 at $500 \mathrm{~m}$ at the Corona Range Livestock Research Center (CRLRC), the Todd Ranch, the Chihuahuan Desert Range Research Center (CDRRC), the Evans Ranch, the Thackeray Ranch and the Carter Ranch.

\begin{tabular}{|c|c|c|c|c|c|c|c|c|c|}
\hline \multirow[t]{2}{*}{ Study Site } & \multicolumn{8}{|c|}{ Number of Associated Cows at HWI >0.5 at $500 \mathrm{~m}$} & \multirow[b]{2}{*}{ Total } \\
\hline & 0 & 1 & 2 & 3 & 4 & 5 & 6 & 7 & \\
\hline CRLRC 2010 & 14 & 0 & 0 & 0 & 0 & 0 & 0 & 0 & 14 \\
\hline CRLRC 2011 & 12 & 0 & 0 & 0 & 0 & 0 & 0 & 0 & 12 \\
\hline CRLRC 2012 & 17 & 0 & 0 & 0 & 0 & 0 & 0 & 0 & 17 \\
\hline Todd Ranch & 12 & 1 & 2 & 0 & 0 & 0 & 0 & 0 & 15 \\
\hline CDRRC & 4 & 4 & 3 & 4 & 1 & 0 & 0 & 0 & 16 \\
\hline Evans Ranch & 3 & 4 & 3 & 2 & 1 & 2 & 0 & 0 & 15 \\
\hline Thackeray Ranch & 2 & 0 & 2 & 5 & 5 & 1 & 0 & 2 & 17 \\
\hline Carter Ranch & 6 & 2 & 3 & 0 & 0 & 0 & 0 & 0 & 11 \\
\hline
\end{tabular}

At the CDRRC and Evans Ranches, at least $75 \%$ of the dyads were greater than $75 \mathrm{~m}$ from each other for over $80 \%$ (i.e., HWI < 0.20 ) of the study period (Figure 1). However, 11 cows at the CDRRC and 10 cows at the Evans Ranch had associations with at least one other cow at HWI values greater than 0.25 at $75 \mathrm{~m}$ (Table 3). At $500 \mathrm{~m}$, greater than $75 \%$ of the dyads at the ranches had HWI values less than 0.5 (Figure 2). Twelve cows at both the CDRRC and Evans Ranches were within $500 \mathrm{~m}$ of at least 1 other cow for greater than $50 \%$ of the GPS locations when cattle were away from water (Table 4 ). Daily mean distance between the most associated dyads at these ranches was often less than $100 \mathrm{~m}$ 
(Figure 4A,B). However, there were periods when the daily mean distances between even the most associated dyads were greater than $500 \mathrm{~m}$ at the CDRRC and $2500 \mathrm{~m}$ at the Evans Ranch.

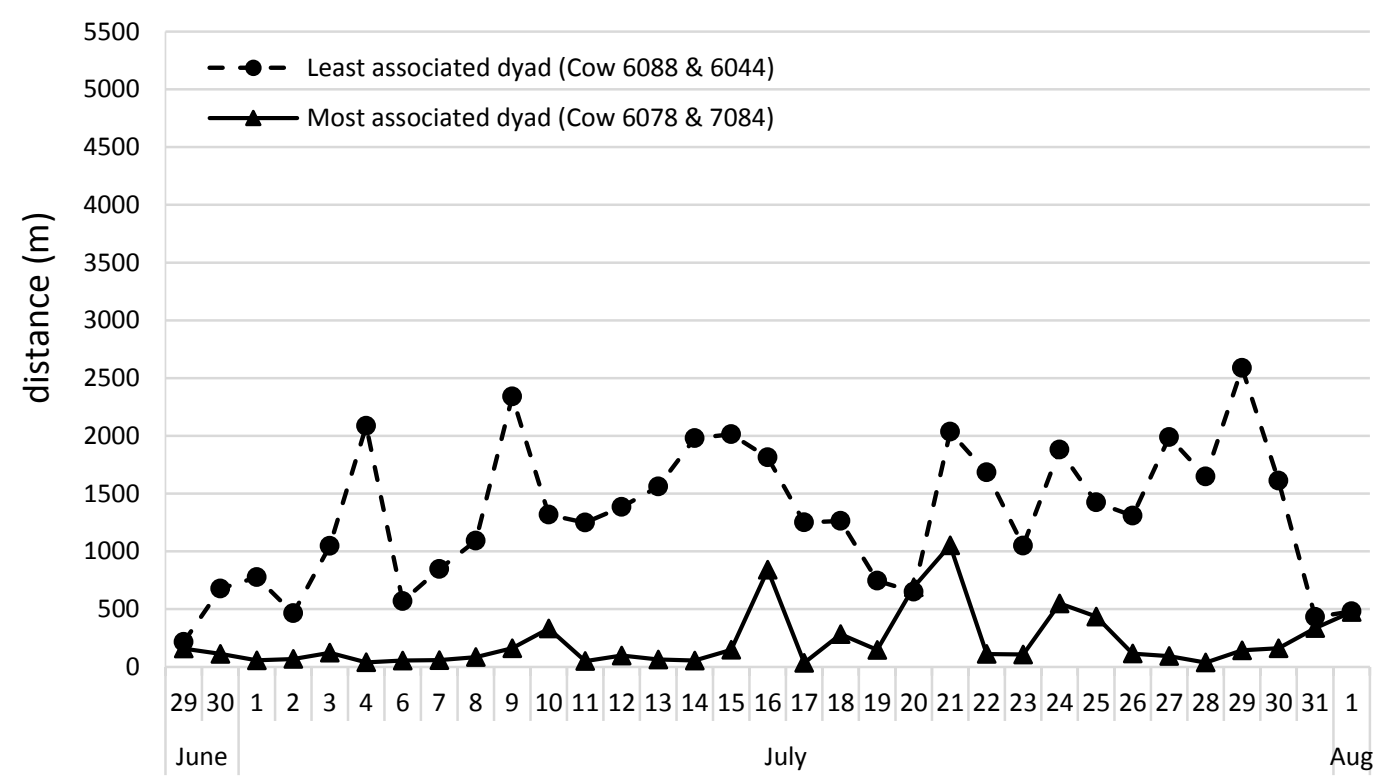

(A)

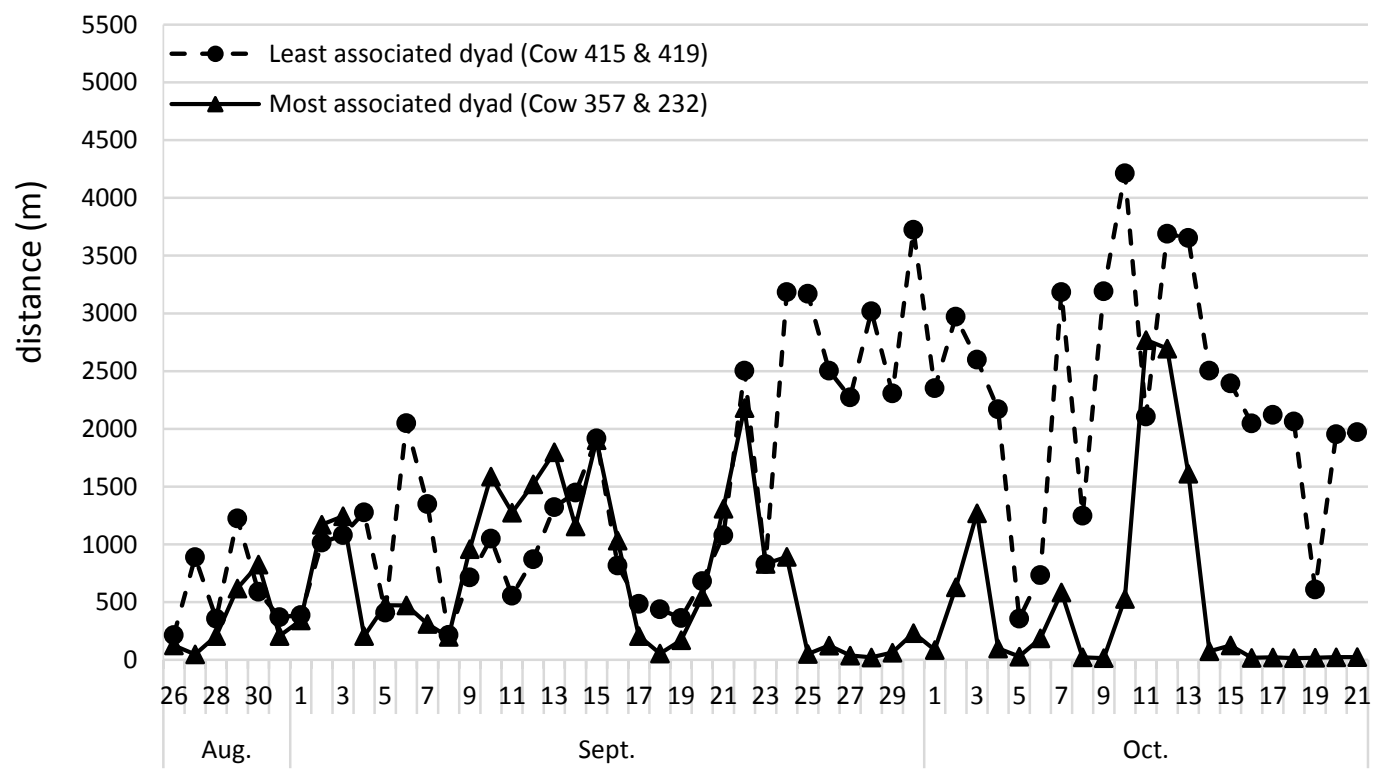

(B)

Figure 4. Mean daily distance between the least and most associated dyad of the GPS-tracked cows at $500 \mathrm{~m}$ at the (A) NMSU Chihuahuan Desert Range Research Center and (B) Evans Ranch study sites.

At the Thackeray Ranch, $72 \%$ and $84 \%$ of the dyads had HWI values less than 0.25 at $75 \mathrm{~m}$ (Figure 1). Seven GPS-tracked cows had associations with at least one other cow at HWI values greater than 0.25 at $75 \mathrm{~m}$ (Table 3). At $500 \mathrm{~m}, 79 \%$ of the dyadic values were less than 0.5 (Figure 2). However, 15 out of the 17 cows were associated with at least one other cow with HWI values greater than 0.5 and two cows were associated with seven other cows at HWI values greater than 0.5 (Table 4). Daily mean distance between cows for the least associated dyad was less than $1000 \mathrm{~m}$ on most days, and daily mean distance between cows in the most associated dyad was usually within $500 \mathrm{~m}$ (Figure 5A). 


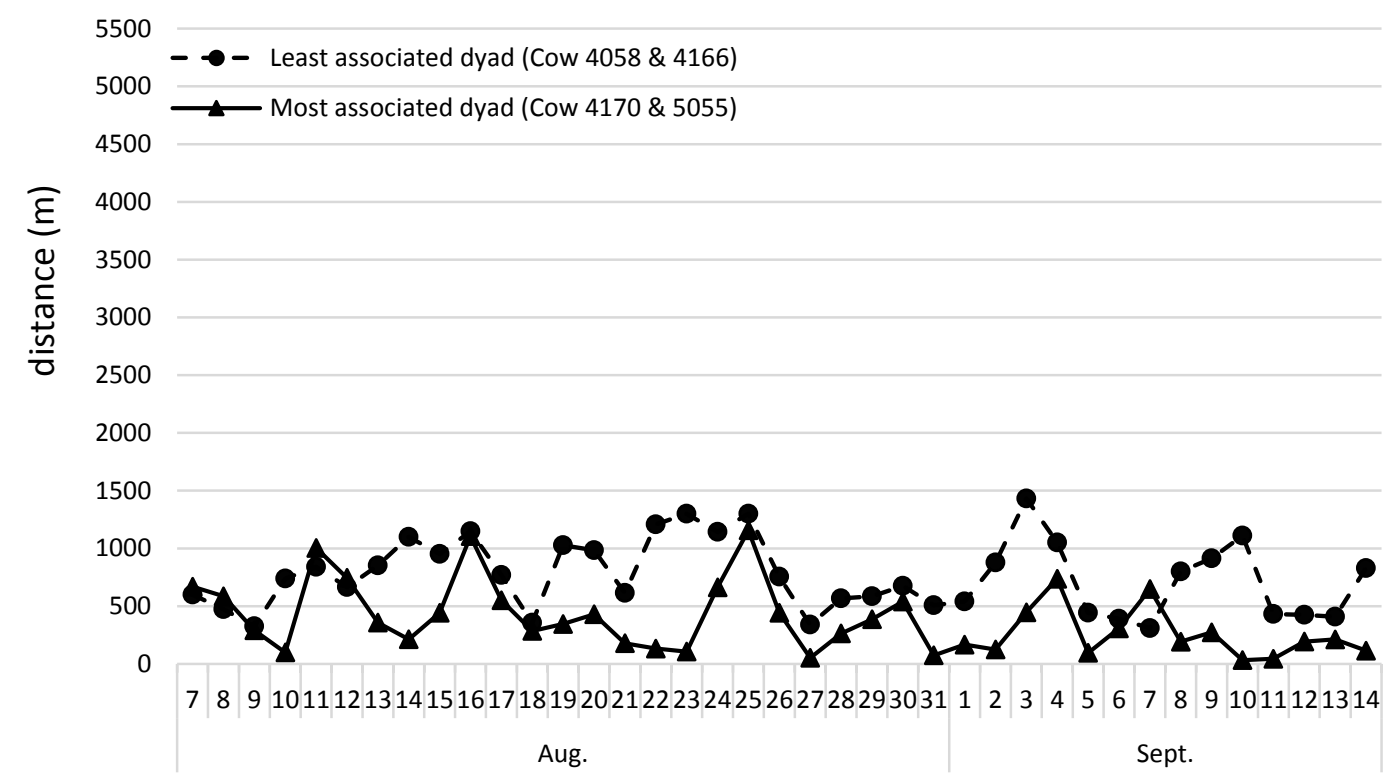

(A)

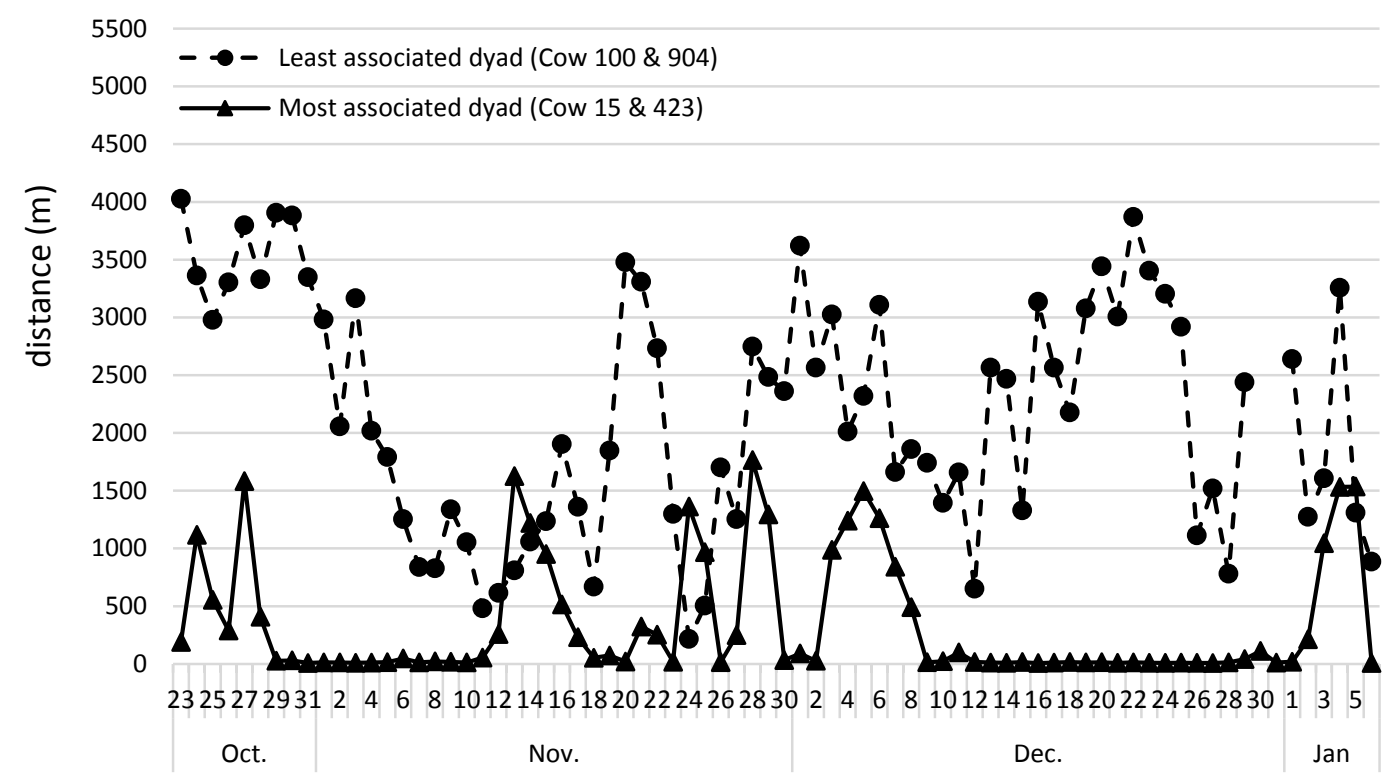

(B)

Figure 5. Mean daily distance between the least and most associated dyad of the GPS-tracked cows at $500 \mathrm{~m}$ at the (A) Thackeray Ranch and (B) Carter Ranch study sites.

At the Carter Ranch, 75\% of the dyads had HWI values less than 0.25 at $75 \mathrm{~m}$, but 10 cows had associations with at least one other cow with HWI values greater than 0.25 (Figure 1; Table 3). At $500 \mathrm{~m}$, dyadic associations ranged from less than 0.1 to greater than 0.7 (Figure 2). Five of the GPS-tracked cows had associations with HWI values greater than 0.5 at $500 \mathrm{~m}$ with other GPS-tracked cows (Table 4). Distance between cows for the most associated dyad at the Carter Ranch was often closer than $100 \mathrm{~m}$, but there were periods when distances were greater than $1500 \mathrm{~m}$ (Figure 5B). 


\section{Discussion}

\subsection{When Are Cattle Movements Independent?}

A critical assumption of this analysis is that the amount of time GPS-tracked cattle spent within a certain distance from each other (i.e., $75 \mathrm{~m}$ and $500 \mathrm{~m}$ ) equated to either association or independence between an individual dyad of GPS-tracked cows. Spatial relationships among cattle are important in understanding the social structure of groups and animals in close proximity to one another will likely exert some influence on each other [30,31].

Animals grazing within the same pasture can influence the movements, grazing locations, and activities of other animals randomly, with attraction, or with avoidance [32]. With the use of ASSOC1, we were able to determine associations between cattle at varying distances from each other, but determining random associations or avoidances of cattle was harder to define. For example, cattle with weak HWI values may not be actively trying to avoid each other, but just exhibiting associations with other cattle or a preference for different areas of the pasture. Cattle typically do not actively avoid or displace other cattle if adequate forage and water resources are available, especially if cattle are familiar with each other [33].

Šárová et al. [34] observed that older cows tended to hold dominance over younger cows, but suggested that larger, younger cows may not contest the dominance of older cows because of few defensible resources when cattle are on pasture. If highly nutritious feeds (i.e., protein or energy supplements) are available in a limited space (i.e., trough or tub), more aggressive or dominant cattle may push less dominant cows away [35]. Because of the expansive areas and few defensible resources at the study sites, it is assumed that cattle within our study pastures likely had little avoidance or displacement influence on each other when they were separated by at least $75 \mathrm{~m}$. Additionally, clear visual contact between cattle at distances greater than $500 \mathrm{~m}$ may not have occurred in many areas of the study pastures because of topography or woody vegetation found in the extensive and/or rugged areas. The distance of influence between cattle on rangelands was likely variable based on topography, vegetation structure, and pasture and herd size. More research is needed to determine appropriate spatio-temporal distances for assigning levels of independence on beef cattle grazing in diverse rangelands.

\subsection{Association of GPS-Tracked Cattle}

The Todd ranch was the only study site to exhibit complete independence for some of the dyads (i.e., HWI $=0.0$ ) for the criteria at the $75 \mathrm{~m}$ and $500 \mathrm{~m}$ spatial scales. The independence of dyads at the Todd Ranch was likely the result of the larger pasture and herd size, rough topography, and multiple watering points the were well distributed throughout the pasture. The most associated dyad had HWI values greater than 0.5 at $500 \mathrm{~m}$, and were separated from other cows within a remote corner of the study pasture with rough topography for much of the study period (see Figure 6). This likely increased their associations with each other because of the spatial separation from other cows. Within extensive rangelands, cattle will often graze within distinct spatially separated areas because of variable topography, heterogeneous vegetation distribution, and/or affinity to particular home range areas $[10,11,36,37]$. Selection of GPS-tracked cattle at the Todd Ranch was based on visual observations of cattle that used either lowlands or rougher topography. This might have facilitated the selection of GPS-tracked cattle that used different home range areas and, therefore, identified several cows that exhibited a high degree of independence compared to some of the other study areas. However, the observational data used to select collared cows were not strongly related to the grazing patterns observed later with GPS tracking data, which indicates that there may have been less bias in cow selection than we initially assumed and planned for [38]. 


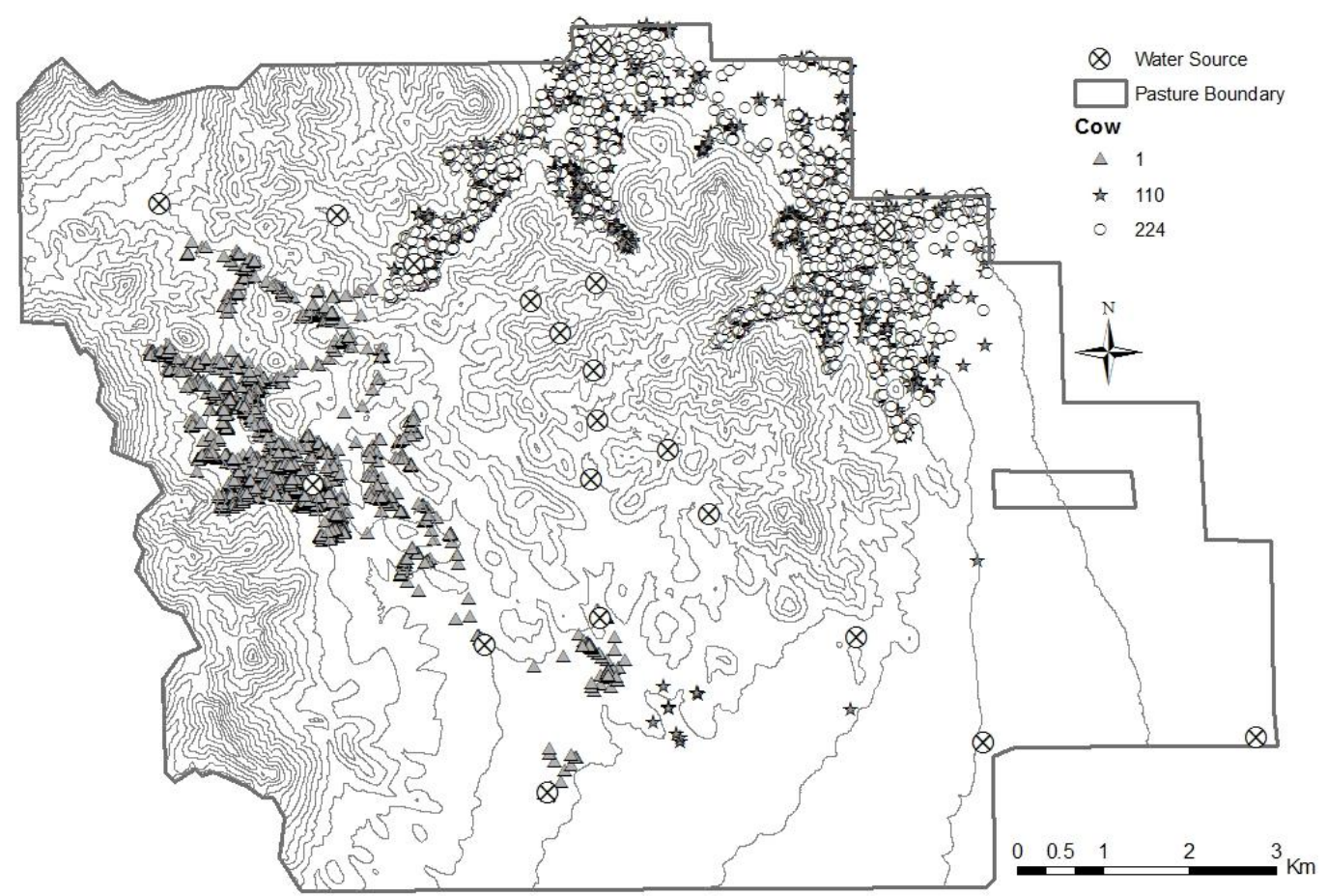

Figure 6. GPS-tracked cattle at the Todd Ranch in western Arizona from 15 January to 15 April 2011 within a 9740 ha pasture. Cow 110 and Cow 224 represent the most associated dyad (Half-Weight Index $(\mathrm{HWI})=0.58)$ of the GPS-tracked cows at $500 \mathrm{~m}$. Cow 1 and Cow 110 were the least associated dyad $(\mathrm{HWI}=0.0)$ at $500 \mathrm{~m}$. Contour lines are $50 \mathrm{~m}$ intervals.

GPS-tracked cows at the CRLRC did not show strong associations (i.e., HWI $<0.43$ at $500 \mathrm{~m}$ ) even though there was only one water source and cattle were constrained to a pasture much smaller than the Todd Ranch. The HWI values for dyads at the CRLRC were well within the $75 \mathrm{~m}$ criteria used by Clark et al. [18] to determine independence of cattle grazing within the same pasture. Low association levels among GPS-tracked cattle at the CRLRC may have been the result of the changing composition of grazing sub-groups of cattle over time. Weber et al. [6] suggested that low mean association levels among elk within the same herd indicated that herds may be functioning as gregarious aggregations rather than discrete social groups, and that tracked elk within this situation could be considered as independent experimental units for home range estimations. Howery et al. [36] observed that cattle grazing within a large pasture in central Idaho, USA generally showed fidelity to a particular home range, but associations between individual cows indicated that social associations of cattle were the result of gregarious behavior rather than strong social bonds. Similarly, Dwyer [39] observed smaller sub-groups of cattle that shifted in individual composition following visits to water or salt locations. Lazo [11] reported that associations of feral cattle at larger home range scales were stable, but that the composition of smaller groupings of cattle within these home ranges were continually changing based on food distribution or other ecological factors. The low association levels of GPS-tracked cows at the CRLRC suggests there was likely minimal interaction and influence between individual dyads, and many of the dyads exhibited a high degree of independence from each other most of the time during the study.

Large pasture size and multiple water locations likely influenced the high variability of association strengths at the Carter Ranch and the number of cows that had associations with at least one other cow at $75 \mathrm{~m}$ or $500 \mathrm{~m}$. Much like at the Todd Ranch, it appears that some cows stayed near different water locations and had strong associations with other cows, while other cows exhibited a high degree of independence. The relatively flat terrain and the relatively smaller pasture size at the Carter Ranch may have limited the complete separation of cattle, as was seen at the Todd Ranch, where at least 
half of the pasture was characterized by rough topography. Rough terrain may be necessary to create spatial separation and the formation of distinct sub-groups of beef cattle [10]. Additionally, before turn out onto the study pasture, all cattle at the Carter Ranch were managed in a dry lot and fed hay for several months. This type of management may have limited group dispersion when cattle were on the study pasture, and increased associations among some GPS-tracked cows.

Greater mean HWI levels at the CDRRC, Thackeray, and Evans Ranches also may have been the result of management scenarios prior to tracking of cattle within the study pastures. Cattle at these ranches were typically separated for at least part of the year into herd breeding management groups and then combined within one pasture during the study period. In contrast, cattle at the CRLRC, Carter, and Todd Ranches were nearly always managed together except when culling, death, and incorporation of replacements resulted in a change to the herd composition. Managing cattle within separate breeding groups in different pastures may influence association levels when cattle are combined into the same pasture. Murphey and de Moura Duarte [40] determined that familiarity of herd mates was more important than breed when cattle formed aggregations on pasture. Other research has indicated that familiarity among cattle in the same pasture affects proximity between cattle and differences in behavior and movements patterns [41,42]. This was especially evident at the CDRRC where HWI association levels for four GPS-tracked cows from one breeding group averaged $0.68 \pm 0.07 \mathrm{SD}$ with each other, and only $0.37 \pm 0.09 \mathrm{SD}$ with cattle from different breeding groups at $500 \mathrm{~m}$ (Stephenson, unpublished data). While these cattle did graze and water with cattle from other groups, they tended to associate predominantly with each other rather than other cattle managed within separate herds before the study period. Sato et al. [43] indicated that unfamiliarity among cattle may influence associations for up to 45 to 60 days before the novelty of unfamiliar herdmates fades. The large number of cows that had associations with at least one other cow (i.e., HWI values greater than the independence criteria and $75 \mathrm{~m}$ and $500 \mathrm{~m}$ ) at the CDRRC was likely the result of failure of the multiple breeding groups to fully integrate into a single herd.

At smaller herd sizes, cattle tend to have greater associations compared to cattle within larger herds $[12,14,44]$. The smaller herd sizes at the CDRRC (i.e., 43 cows) and Evans Ranches (i.e., 37 cows) may have influenced associations of cattle based on a limited number of companions. Stephenson et al. [13] determined that smaller herds (i.e., 27 to 40 cow-calf pairs) tended to function as a single unit with many of the cattle being observed within the same grazing group (i.e., cattle within $30 \mathrm{~m}$ ) at least once over a one to two month summer grazing period. In contrast, larger herds (i.e., 53 to 240 cows) tended to form into multiple groups with associations between dyads that were stronger than what would be expected from chance. Harris et al. [12] found that small cattle herds grazing California rangelands, with 14 to 16 animals, were usually located within 50 to $125 \mathrm{~m}$ of each other. Bailey et al. [4] used only one GPS-tracked cow to determine the distribution characteristics of herds of six animals because visual observations indicated that cattle were never more than $100 \mathrm{~m}$ from each other. Because of stronger associations in small herds, caution should be taken when evaluating if individual cows behave independently and can be used appropriately as experimental units.

Most dyads at the Thackeray Ranch did not meet the criteria for independence at the $500 \mathrm{~m}$ spatial scale. Cattle at the Thackeray Ranch were constrained to a smaller pasture than the other study sites. The smaller pasture size likely increased the number of instances when GPS-tracked cows were near each other. However, because of the rough topography within the study pasture it is likely that dyads would not be able to see one another at distances greater than 200 to $500 \mathrm{~m}$ within many areas of the pasture because of ridges, swales, and other topographic features [45]. In addition to the smaller pasture size, all GPS-tracked cows were half-siblings and usually managed separately from the other cattle in the study pasture. The combination of small pasture size and unfamiliarity with the non-GPS-tracked cattle in the herd likely caused the higher HWI associations and the high number of cattle with at least one associate at the Thackeray Ranch.

Overall, cattle at the CRLRC and the Todd Ranch exhibited the highest degree of independence at $75 \mathrm{~m}$ and $500 \mathrm{~m}$ independence criteria. At the Todd Ranch 3 cows were associated based on the criteria 
(i.e., greater than $50 \%$ of the fix locations within $500 \mathrm{~m}$ ). In situations where one or a few individuals were associated within the same area, Frair et al. (2007) indicated that removing one or more of the associated individuals could reduce the risk of pseudo-replication. Due to several factors, many cattle at the Evans, CDRRC, Thackeray, and Carter Ranch study sites exhibited associations with at least one or more other cows that exceeded the criteria for independence, and thus the use of individual cows as the experimental unit would have not been appropriate for some research questions such as resource selection analyses [18]. Seventy-five percent or more of the dyadic associations at these study sites usually met the criteria for independence and, depending on the question of interest, individual cow or groups of cows could potentially be considered sufficiently independent to be used as the experimental unit. However, caution should be taken when applying independence criteria and evaluating if cattle behave independently within small herds, when cattle are managed separately and combined into a communal pasture, or when cattle can become spatially separated within a large pasture.

\subsection{Number of GPS-Tracked Animals}

The appropriate number of GPS-tracked cows that are required to evaluate movements and behaviors of an entire herd is difficult to determine, and is likely variable for different herds. Tracking studies of livestock are usually limited to relatively few collars because of the high cost [5]. Hunt et al. [46] cautioned that tracking a small number of cows within larger herds might not provide a good sample to draw inference from, because not all sub-groups of cattle are adequately represented. However, the composition of individuals within sub-groups of cows may change regularly within some scenarios, and sampling of all sub-groups may not be a requirement to obtain a representative sample. Cattle are often gregarious and may not form strong associations with other individuals, but rather have associations in many different groups within the same pasture or home range area $[36,39,47]$. Grazing in multiple groups or regular separation from associated individuals was evident in the current study, as even the most highly associated individuals at the different study sites were often tracked for several days at distances of greater than $1 \mathrm{~km}$ from each other (e.g., the most associated dyad at the CRLRC, See Figure 3A).

By randomly assigning GPS-collars to cows, movements of the herd, a composite of a large number of sub-groups, may be accurately sampled without purchasing a large number of GPS collars, because cattle may shift between various sub-groups, and the probability of sampling any sub-group should be relatively equal. This is likely more evident in situations where home range areas overlap because of small pasture sizes and where dominance hierarchies are well established because the individual composition of the herd remains relatively constant (e.g., CRLRC). Periodic rotation among pastures also may affect the strength of social associations and fidelity to sub-groups, because cattle adapt to regrouping events [48]. When cattle are moved among smaller pastures, cattle become mixed and there is less time for spatial home range preferences to develop, or corresponding isolation among individuals. In contrast, cattle can become isolated in very large pastures with rugged terrain that are grazed yearlong (e.g., Todd Ranch). Correspondingly, fidelity to sub-groups can increase and cattle groups can become less familiar with each other. Likewise, fidelity to sub-groups may increase when unfamiliar cattle are placed in the same pastures (e.g., CDRRC). When fidelity to sub-groups is high because of such situations, concerns with sampling herds with a small number of GPS collars is valid, and stratified random sampling of all sub-groups would be necessary to achieve a representative sample. However, until the cost of GPS-tracking cattle becomes more reasonable, the number of tracked individuals may be determined more by economics rather than statistical sampling estimations, such as power analyses.

\section{Conclusions}

Use of individual animals as the experimental unit for statistical inference in GPS-tracking livestock studies depends on the experimental design of the study and the characteristics of the pasture, herd, and previous management of cattle. While interactions among cattle in the same pasture 
are often inevitable, our data suggests that many dyadic associations within a random or semi-random sub-set of GPS-tracked cattle may be predominantly independent of each other, or it at least can be argued that associations among some dyads would have minimal influence on the behaviors of each other.

As indicated by previous research $[6,12,18]$, the software program ASSOC1 provides a valuable resource in determining association patterns and independence of GPS-tracked cattle based on the proportion of positions that animals are within a specified distance from one another. Greater resources, reduced costs, and increased opportunities to track livestock with GPS collars will continue to improve our understanding of livestock distribution and grazing behavior. Although it is usually unreasonable to assume that cattle within the same pastures are completely independent and do not interact, it may be overly cautious to avoid all experimental designs that use animal as the experimental unit, because complete independence among all cows cannot be established. In grazing behavior studies evaluating large herds of cattle grazing within extensive, topographically diverse pastures that are managed using typical livestock husbandry practices, individual cows may be sufficiently independent in some situations to adequately evaluate many research questions.

Acknowledgments: Western Sustainable Agriculture Research and Education Program provided partial funding for this project. We would like to thank Bart Carter and family (Carter Ranch), Erin and Dick Evans and family (Evans Ranch), and Tom Todd and family (Todd Ranch) for gracious and insightful cooperation in this study. We would also like to thank and acknowledge the efforts of Adrianne Lipka, Steven Lunt, Delyn Jensen, Laura Goodman, Robin Weinmeister and Robert "Bob" Welling in collecting the cattle tracking data used in this study.

Author Contributions: All authors have read and approved the final manuscript.

Conflicts of Interest: The authors declare no conflict of interest.

\section{References}

1. Ganskopp, D. Manipulating cattle distribution with salt and water in large arid-land pastures: A GPS/GIS assessment. Appl. Anim. Behav. Sci. 2001, 73, 251-262. [CrossRef]

2. Ganskopp, D.; Bohnert, D. Do pasture-scale nutritional patterns affect cattle distribution on rangelands? Rangel. Ecol. Manag. 2006, 59, 189-196. [CrossRef]

3. Bailey, D.W.; VanWagoner, H.C.; Weinmeister, R.; Jensen, D. Evaluation of low-stress herding and supplement placement for managing cattle grazing in riparian and upland areas. Rangel. Ecol. Manag. 2008, 61, 26-37. [CrossRef]

4. Bailey, D.W.; Thomas, M.G.; Walker, J.W.; Witmore, B.K.; Tolleson, D. Effect of previous experience on grazing patterns and diet selection of Brangus Cows in the Chihuahuan desert. Rangel. Ecol. Manag. 2010, 63, 223-232. [CrossRef]

5. Swain, D.L.; Friend, M.A.; Bishop-Hurley, G.J.; Handcock, R.N.; Wark, T. Tracking livestock using global positioning systems-Are we still lost? Anim. Prod. Sci. 2011, 51, 167-175. [CrossRef]

6. Weber, K.T.; Burcham, M.; Marcum, C.L. Assessing independence of animal locations with association matrices. J. Range Manag. 2001, 54, 21-24. [CrossRef]

7. Valcu, M.; Kempenaers, B. Spatial autocorrelation: An overlooked concept in behavioral ecology. Behav. Ecol. 2010, 21, 902-905. [CrossRef] [PubMed]

8. Boyce, M.S.; Pitt, J.; Northrup, J.M.; Morehouse, A.T.; Knopff, K.H.; Cristescu, B.; Stenhouse, G.B. Temporal autocorrelation functions for movement rates from global positioning system radio telemetry data. Philos. Trans. R. Soc. B 2010, 365, 2213-2219. [CrossRef] [PubMed]

9. Perotto-Baldivieso, H.L.; Cooper, S.M.; Cibils, A.F.; Figueroa-Pagan, M.; Udaeta, K.; Black-Rubio, C.M. Detecting autocorrelation problems from GPS collar data in livestock studies. Appl. Anim. Behav. Sci. 2012, 136, 117-125. [CrossRef]

10. Roath, L.R.; Krueger, W.C. Cattle grazing and behavior on a forested range. J. Range Manag. 1982, 35, 332-338. [CrossRef]

11. Lazo, A. Social segregation and the maintenance of social stability in a feral cattle population. Anim. Behav. 1994, 48, 1133-1141. [CrossRef] 
12. Harris, N.R.; Johnson, D.E.; McDouglad, N.K.; George, M.R. Social associations and dominance of individuals in small herds of cattle. Rangel. Ecol. Manag. 2007, 60, 339-349. [CrossRef]

13. Stephenson, M.B.; Bailey, D.W.; Jensen, D. Associations patterns of visually-observed cattle on Montana, USA foothill rangelands. Appl. Anim. Behav. Sci. 2016, 178, 7-15. [CrossRef]

14. Hacker, R.B.; Norton, B.E.; Owens, M.K.; Frye, D.O. Grazing crested wheatgreass, with particular reference to effects of pasture size. J. Range Manag. 1988, 41, 73-78. [CrossRef]

15. Rook, A.J.; Penning, P.D. Synchronisation of eating, ruminating and idling activity by grazing sheep. Appl. Anim. Behav. Sci. 1991, 32, 157-166. [CrossRef]

16. Hurlbert, S.H. Pseudoreplication and the design of ecological field experiments. Ecol. Monogr. 1984, 54, 187-211. [CrossRef]

17. Anderson, D.M. Geospatial methods and data analysis for assessing distribution of grazing livestock. In Proceedings of the 4th Grazing Livestock Nutrition Conference, Estes Park, CO, USA, 9-10 July 2010; pp. 57-90.

18. Clark, P.E.; Lee, J.; Ho, K.; Nielson, R.M.; Johnson, D.E.; Ganskopp, D.C.; Chigbrow, J.; Pierson, F.B.; Hardegree, S.P. Prescribed fire effects on resource selection by cattle in mesic sagebrush steppe. Part 1 : Spring grazing. J. Arid Environ. 2014, 100, 78-88. [CrossRef]

19. Bailey, D.W.; Lunt, S.; Lipka, A.; Thomas, M.G.; Medrano, J.F.; Cánovas, A.; Rincon, G.; Stephenson, M.B.; Jensen, D. Genetic influences on cattle grazing distribution: Association of genetic markers with terrain use in cattle. Rangel. Ecol. Manag. 2015, 68, 142-149. [CrossRef]

20. Bailey, D.W.; Marta, S.; Jensen, D.; Boss, D.L.; Thomas, M.G. Genetic and environmental influences on distribution patterns of beef cattle grazing foothill rangeland. Proc. West. Sect. Am. Soc. Anim. Sci. 2010, 61, 64-66.

21. Frair, J.L.; Merrill, E.H.; Allen, J.R.; Boyce, M.S. Know thy enemy: Experience affects elk translocation success in risky landscapes. J. Wildl. Manag. 2007, 71, 541-554. [CrossRef]

22. Long, R.A.; Rachlow, J.L.; Kie, J.G. Effects of season and scale on response of elk and mule deer to habitat manipulation. J. Wildlife Manag. 2008, 72, 1133-1142. [CrossRef]

23. Long, R.A.; Muir, J.D.; Rachlow, J.L.; Kie, J.G. A comparison of two modeling approaches for evaluating wildlife-habitat relationships. J. Wildlife Manag. 2009, 73, 294-302. [CrossRef]

24. Lendrum, P.E.; Anderson, C.R., Jr.; Long, R.A.; Kie, J.G.; Bowyer, R.T. Habitat selection by mule deer during migration: Effects of landscape structure and natural-gas development. Ecosphere 2012, 3, 1-19. [CrossRef]

25. Bailey, D.W.; Gross, J.E.; Laca, E.A.; Rittenhouse, L.R.; Coughenour, M.B.; Swift, D.M.; Sims, P.L. Mechanisms that result in large herbivore grazing distribution patterns. J. Range Manag. 1996, 49, 386-400. [CrossRef]

26. Whitehead, H. Analyzing Animal Societies: Quantitative Methods for Vertebrate Social Analysis; University of Chicago Press: Chicago, IL, USA, 2008; p. 336.

27. Finger, A.; Patison, K.P.; Heath, B.M.; Swain, D.L. Changes in the group associations of free-ranging beef cows at calving. Anim. Prod. Sci. 2014, 54, 270-276. [CrossRef]

28. Shaw, R.A. Social organization and decision making in North American Bison: Implications for management. Ph.D. Thesis, Utah State University, Logan, UT, USA, 2012; p. 123.

29. Cairns, S.J.; Schwager, S.J. A comparison of association indexes. Anim. Behav. 1987, 35, 1454-1469. [CrossRef]

30. Stricklin, W.R. Matrilinear social dominance and spatial relationships among Angus and Hereford cows. J. Anim. Sci. 1983, 57, 1397-1405. [CrossRef] [PubMed]

31. Boe, K.E.; Faerevik, G. Grouping and social preferences in calves, heifers, and cows. Appl. Anim. Behav. Sci. 2003, 80, 175-190. [CrossRef]

32. Minta, S.C. Tests of spatial and temporal interactions among animals. Ecol. Appl. 1992, 2, 178-188. [CrossRef] [PubMed]

33. Sowell, B.F.; Mosley, J.C.; Bowman, J.P.G. Social behavior of grazing beef cattle: Implications for management. Proc. Am. Soc. Anim. Sci. 1999, 78, E18. [CrossRef]

34. Šárová, R.; Špinka, M.; Stěhulová, I.; Cearcero, F.; Šimečková, M.; Kotrba, R. Pay respect to the elders: Age, more than body mass, determines dominance in female beef cattle. Anim. Behav. 2013, 86, 1315-1323. [CrossRef]

35. Bowman, J.G.; Sowell, B.F. Delivery method and supplement consumption by grazing ruminants: A review. J. Anim. Sci. 1997, 75, 543-550. [CrossRef] [PubMed] 
36. Howery, L.D.; Provenza, F.D.; Banner, R.E.; Scott, C.B. Differences in home range and habitat use among individuals in a cattle herd. Appl. Anim. Behav. Sci. 1996, 49, 305-320. [CrossRef]

37. Howery, L.D.; Provenza, F.D.; Banner, R.E.; Scott, C.B. Social and environmental factors influence cattle distribution on rangeland. Appl. Anim. Behav. Sci. 1998, 55, 231-244. [CrossRef]

38. Lunt, S.T. Modifying individual grazing distribution patterns of cows in extensive rangeland pastures through genetic selection. Master's Thesis, New Mexico State University, Las Cruces, NM, USA, 2013; p. 122.

39. Dwyer, D.D. Activities and Grazing Preferences of Cow with Calves in Northern Osage County, Oklahoma; Oklahoma Agricultural Experiment Station: Stillwater, OK, USA, 1961; p. 61.

40. Murphey, R.M.; de Moura Duarte, F.A. Social aggregations in cattle. II. Contributions of familiarity and genetic similarity. Behav. Genet. 1990, 20, 355-368. [CrossRef] [PubMed]

41. Takeda, K.; Sato, S.; Sugawara, K. The number of farm mates influences social and maintenance behaviours of Japanese black cows in a communal pasture. Appl. Anim. Behav. Sci. 2000, 67, 181-192. [CrossRef]

42. Patison, K.P.; Swain, D.L.; Bishop-Hurley, G.J.; Robins, G.; Pattison, P.; Reid, D.J. Changes in temporal and spatial associations between pairs of cattle during the process of familiarization. Appl. Anim. Behav. Sci. 2010, 128, 10-17. [CrossRef]

43. Sato, S.H.; Sassa, H.; Sonoda, T. The change in social behaviour of newly introduced heifers with original group cows. Anim. Sci. Technol. 1991, 62, 83-92. [CrossRef]

44. Laca, E.A. New approaches and tools for grazing management. Rangel. Ecol. Manag. 2009, 62, $407-417$. [CrossRef]

45. Bailey, D.W.; Keil, M.R.; Rittenhouse, L.R. Daily movement patterns of hill climbing and bottom dwelling cows. J. Range Manag. 2004, 57, 20-28. [CrossRef]

46. Hunt, L.P.; Petty, S.; Cowley, R.; Fisher, A.; Ash, A.J.; MacDonald, N. Factors affecting the management of cattle grazing distribution in northern Australia: Preliminary observations on the effect of paddock size and water points. Rangel. J. 2007, 29, 169-179. [CrossRef]

47. Kimura, D.; Ihobe, H. Feral cattle (Bos taurus) on Kuchinoshima Island, southwestern Japan: Their stable ranging and unstable grouping. J. Ethol. 1985, 3, 39-47. [CrossRef]

48. Mench, J.A.; Swanson, J.C.; Stricklin, W.R. Social stress and dominance among group members after mixing beef cows. Can. J. Anim. Sci. 1990, 70, 345-354. [CrossRef] 